\title{
Особливості реалізації стандартних положень під час розіграшу м’яча з позиції «check-ball»» командами високої квалісрікації в баскетболі 3 × 3
}

\author{
Володимир Холопов, Микола Безмилов
}

\author{
Федерація баскетболу України, Київ, Україна
}

Анотація. Аналіз специсрічних умов змагальної діяльності в баскетболі $3 \times 3 €$ одним із перспективних напрямів удосконалення системи підготовки спортсменів для їх подальшого виступу на найпрестижніших міжнародних змаганнях. Розуміння ключових структурних елементів змагальної діяльності, компонентів їх забезпечення та реалізації, має важливу перевагу над суперниками. Особливої актуальності ці проблеми набувають на олімпійському етапі розвитку баскетболу $3 \times 3$. Мета. Охарактеризувати основні принципи взаємодії гравців під час виконання стандартних положень розіграшу м'яча з позиції «check-ball» та визначити ефрективність їх реалізації у змагальній діяльності провідних баскетбольних збірних команд світу. Методи. Аналіз літературних джерел та мережі Інтернет, педагогічне спостереження, аналіз змагальної діяльності, відеоаналіз ігор, методи математичної статистики. Результати. Національні збірні команди з баскетболу $3 \times 3$ виконують протягом поєдинку до $11 \pm 0,68$ розіграшів м'яча 3 позиції «check-ball». При цьому лише $37,52 \pm 12,9$ \% таких атак у чоловічих командах є результативними. Для жіночих збірних цей показник ще нижчий $-33,58 \pm 16,16 \%$. Найбільша кількість атак зі стандартного положення «check-ball» спостерігається в перші 2-3 хв матчу, найменша кількість - у завершальній стадії гри $(\mathrm{p}<0,05)$. Кращий відсоток реалізації стандартних положень команди високого класу демонструють у заключні хвилини поєдинку. Під час організації стандартних положень розіграшу м'яча з позиції «check-ball» необхідно враховувати ряд важливих факторів: склад своєї команди; склад команди суперника; новизна обраних комбінацій; оперативна ситуація під час матчу.

Ключові слова: стандартне положення «check-ball», структура змагальної діяльності, нерівноцінний розмін «mismatch», скаутинг.

\section{Volodymyr Kholopov, Mykola Bezmylov}

\section{FEATURES OF STANDARD POSITION REALIZATION DURING PLAYING THE BALL FROM THE POSITION OF «CHECK-BALL» BY HIGHLY QUALIFIED TEAMS IN BASKETBALL $3 \times 3$}

Abstract. Analysis of competitive activity specific conditions in $3 \times 3$ basketball is one of the promising areas for improving the system of training athletes for their further performance at the most prestigious international competitions. Understanding the key structural elements of competitive activity, the components of their provision and implementation, provides an importan advantage over the opponents. These problems become especially relevant at the Olympic stage of basketball development $3 \times 3$. Objective. Describe the basic principles of players' interaction during the implementation of the standard positions of playing the ball from the position of «check-ball» and determine the effectiveness of their implementation in the competitive activities of the world best basketball teams. Methods. Analysis of literary sources and the Internet, pedagogical observation, analysis of competitive activities, video analysis of games, methods of mathematical statistics. Results. The national $3 \times 3$ basketball teams perform up to $11 \pm 0.68$ check-balls during the match. At the same time, only $37.52 \pm 12.9 \%$ of such attacks in men's teams are effective. For women's national teams, this figure is even lower $-33.58 \pm 16.16 \%$. The largest number of attacks from the standard position of «check-ball» is observed in the first 2-3 minutes of match, whereas the smallest - in the final stage of the game $(p<0,05)$. The best percentage of the realization of the standard positions of the high-class team is demonstrated in the final minutes of the match. When organizing the standard positions of the ball playing from the position of «check-ball» it is necessary to take into account a number of important factors: the composition of your team; the composition of the opponent's team; novelty of selected combinations; operational situation during the match.

Keywords: «check-ball» standard position, competitive activity structure, «mismatch», scouting

Kholopov V, Bezmylov M. Features of standard position realization during playing the ball from the position of «check-ball» by highly qualified teams in basketball $3 \times 3$. Theory and Methods of Physical education and sports. 2020; 4: 43-52

DOI: 10.32652/tmfvs.2020.4.43-52
Холопов В., Безмилов М. Особливості реалізації стандартних положень під час розіграшу м'яча з позиції «check-ball» командами високої кваліфрікації в баскетболі $3 \times 3$. Теорія і методика фрізичного виховання і спорту. 2020; 4: 43-52 DOI: 10.32652/tmfvs.2020.4.43-52
Вступ. Одним із важливих напрямів удосконалення системи спортивної підготовки $є$ підвищення якості управління тренувальним процесом на основі об'єктивізації знань про структуру змагальної діяльності та підготовленості з урахуванням як загальних закономірностей становлення спортивної майстерності в конкретному виді спорту, так і індивідуальних можливостей спортсменів [1-3].

Знання структури змагальної діяльності в конкретному виді спорту, факторів ії забезпечення та реалізації створюють передумови для досягнення заданого спортивного результату. Особливої актуальності проблема дослідження структури змагальної діяльності набуває в тих видах спорту, які нещодавно отримали міжнародне визнання та були включені до програми Олімпійських ігор. Розуміння ключових структурних ланок змагальної діяльності, компонентів їх забезпечення та реалізації створює суттєву перевагу над суперниками, особливо на перших етапах розвитку нового виду спорту.

Останнім часом все більшої популярності у світі та в Україні набуває баскетбол $3 \times 3$. Баскетбол $3 \times 3$, або вуличний баскетбол (street ball), як його ще інколи називають, з'явився в середині XX ст. на вуличних майданчиках у США як засіб активного відпочинку та спілкування серед молоді [10]. Для проведення гри було достатньо лише одного кошика, який міг кріпитися на стіну будівлі. Значно пізніше для проведення ігор з вуличного баскетболу стали створювати спеціальні майданчики та проводити офріційні змагання.

Стрімкий розвиток вуличного баскетболу як виду спорту розпочався у 2007 р., коли Міжнародна федерація баскетболу (FIBA) стала регулярно проводити рейтингові змагання з цього виду спорту. Саме тоді вуличний 
баскетбол отримує нову назву - баскетбол $3 \times 3$.

Включення баскетболу $3 \times 3$ до програми Ігор Олімпіад 2020 р. стало значним каталізатором наукових досліджень проблем раціональної підготовки баскетболістів високого класу до міжнародних змагань. Такі публікації почали з'являтися в спеціальній літературі нещодавно, переважно в зарубіжних виданнях. При цьому значна кількість таких робіт була спрямована на вивчення відмінностей структури змагальної діяльності в баскетболі $3 \times 3$ порівняно 3 класичним баскетболом $5 \times 5$ [4-9].

Характерною особливістю змагальної діяльності баскетболу $3 \times 3$ на відміну від класичного баскетболу $5 \times 5 €$ менша тривалість поєдинку. В класичному баскетболі матч триває 40 хв «чистого» ігрового часу, в баскетболі $3 \times 3$ - лише 10 хв. На атаку відводиться 12 с (вдвічі менше, ніж у класичному баскетболі) [11]. Гра проходить більш динамічно та імпульсивно. Висока інтенсивність рухових дій вимагає від гравців значної фрункціональної підготовленості. До складу команди 3 баскетболу $3 \times 3$ входять чотири гравці, три 3 яких постійно знаходяться на майданчику.

Дослідження [7] показали, що фрізичні навантаження в баскетболі $3 \times 3$ вдвічі перевищують аналогічні показники класичного баскетболу. Автори розрахували «дозу» навантажень, яку отримують спортсмени за 1 хв ігрового часу, на основі аналізу різноманітних рухових дій (прискорення, стрибки, зміни напрямку рухів, загальна пройдена дистанція тощо)

Схожі дані були опубліковані А. Herrán зі співавт. [6], які за допомогою сучасної GPS-системи аналізу рухів дій спортсменів (Catapult Sport) досліджували особливості кінематичних параметрів змагальної діяльності баскетболістів у класичному баскетболі та баскетболі $3 \times 3$. Спортсмени в баскетболі 3 × 3 попри загальну меншу пройдену дистанцію за матч (м), отримували більшу «дозу» фрізичного навантаження за 1 хв ігрового часу (ум. од.). Було визначено, що кількість прискорень понад 1,5 та $2 \mathrm{~m} \cdot \mathrm{c}^{-1} \mathrm{y}$ спортсменів в баскетболі $3 \times 3$ майже втричі більша, ніж під час класичної гри. В баскетболі $5 \times 5$ спостерігалась більша кількість повільних переміщень гравців - менше $0,5 \mathrm{M} \cdot \mathrm{c}^{-1}$ (удвічі порівняно із баскетболом $3 \times 3$ ).

При цьому більш висока інтенсивність рухової діяльності супроводжується меншою тривалістю ігрових відрізків та досить короткими інтервалами відпочинку. За деякими даними [4], співвідношення ігрового часу (LT) та часу відпочинку (ST) в паузах гри $3 \times 3$ наближається до одиниці $0,92 \pm 0,13$. У класичному баскетболі тривалість ігрового відрізку у півторадва рази довша, ніж тривалість зупиHOK.

Суттєві відмінності спостерігаються й у структурі виконання різноманітних кидків. Проведені словенськими фахівцями на чолі із Frane Erculj [5] дослідження показали, що під час баскетбольного матчу $3 \times 3$ виконується значно більша кількість дальніх (6,75 м) та штрафнних кидків при меншому відсотку їх реалізації порівняно із класичною грою. Учені пояснюють такий розподіл кидків специфічними умовами змагальної діяльності в баскетболі $3 \times 3$.

Більша кількість дальніх кидків може бути обумовлена їх «ваговою» значущістю для загального рахунку в матчі. Адже за влучний кидок із-за дуги в баскетболі $3 \times 3$ зараховуються два очки, всі інші приносять лише одне. В класичному баскетболі влучний кидок із-за дуги дає команді три очки, а кидки з ближчої дистанції зараховуються за два. Різниця набраних очок у баскетболі $3 \times 3$ дальньої та ближньої дистанції більш суттєва, що, скоріше за все, й визначило той розподіл, який спостерігали дослідники. Менший відсоток реалізації кидків, на їхню думку, пов'язаний із впливом специфрічних фракторів, які відрізняють баскетбол $3 \times 3$ від класичної гри, а саме: гра на відкритому майданчику (вплив вітру на траєкторію кидка), значна втома гравців під час виконання кидків (особливо у другій частині матчу) та суттєвий десріцит часу на атаку кошика суперника, що досить часто призводить до виконання недостатньо підготовлених кидків у матч (менше 2 с тощо).
Подібна вибіркова спрямованість наукових досліджень зарубіжних фахівців у визначенні специфрічних відмінностей класичного баскетболу від баскетболу $3 \times 3 \epsilon$, на наш погляд, 30всім не випадковим явищем. Адже до останнього часу ці два різновиду баскетболу постійно перетиналися. Професійні баскетболісти із класичного баскетболу після закінчення ігрового клубного сезону запрошувались до лав національних збірних команд і після нетривалої підготовки (приблизно місяць) брали участь в найпрестижніших міжнародних змаганнях FIBA $3 \times 3$ (чемпіонати світу, Європи).

Рівень майстерності цих баскетболістів був настільки високим, що вони з легкістю обігрували аматорів, які займалися лише баскетболом $3 \times 3$. Відведеного часу гравцям цілком вистачало для того, щоб адаптуватися до неспецифічних умов ведення змагальної діяльності (зміна покриття, менша кількість учасників, гра на відкритих майданчиках тощо) та успішно виступити на майбутніх змаганнях.

Такий підхід був дуже поширеним у перші роки міжнародного становлення баскетболу $3 \times 3$. Національні збірні, які комплектували склади своїх команд шляхом залучення професійних гравців з баскетболу $5 \times 5$, у період міжсезоння мали значну перевагу над суперниками та з легкістю здобували найвищі нагороди престижних турнірів.

Ситуація почала стрімко змінюватися після того, як баскетбол $3 \times 3$ було включено до програми Ігор Олімпіади 2020. FIBA $3 \times 3$ створює власну систему міжнародних змагань для клубних і збірних команд, виступ на яких починає впливати на загальний рейтинг та право кваліфікуватися на престижні турніри.

У баскетболі $3 \times 3$ з'явився свій власний ігровий сезон, який включає велику кількість турнірів, «мастерсів», «квестів», «челенджерів», «сателітів» та інших престижних змагань. Тривалість ігрового клубного сезону в баскетболі $3 \times 3$ вже сьогодні становить 6-7 міс. Спостерігається тенденція до подальшого збільшення кількості турнірів та ігор. 
Проведення головних міжнародних турнірів національних збірних команд $3 \times 3$ сьогодні дуже часто відбуваєтьсяв ві самітерміни, що йзмагання 3 класичного баскетболу. Дехто вбачає в цьому свідомі дії спортивних функціонерів FIBA, спрямовані на те, щоб відокремити подальший розвиток двох різновидів баскетболу та створити специфічну систему спортивних змагань у баскетболі $3 \times 3$ із подальшою поглибленою підготовкою до них. У таких умовах суттєвим чином підвищується значущість наукових досліджень та методичних розробок, спрямованих на пошук ефективних шляхів цілеспрямованої підготовки спортсменів до міжнародних змагань з баскетболу $3 \times 3$.

Одним із актуальних напрямів наукового дослідження змагальної діяльності в баскетболі $3 \times 3$, на наш погляд, $€$ аналіз організації та виконання так званих стандартних положень в грі («check-ball»). В баскетболі $5 \times 5$ подібний розіграш м'яча відсутній.

Ефективні дії команди під час розіграшу м'яча з позиції «check-ball» можуть стати запорукою вдалого виступу в матчі та на турнірі в цілому. Цікавим $€$ вивчення досвіду реалізації стандартних положень провідними баскетбольними збірними командами світу, розгляд різних варіантів тактичних взаємодій баскетболістів та виділення ключових принципів, якими керуються під час розіграшу стандартних положень у баскетболі $3 \times 3$.

Мета дослідження - охарактеризувати основні принципи взаємодії гравців під час виконання стандартних положень розіграшу м'яча з позиції «check-ball» та визначити ефективність їх реалізації в змагальній діяльності провідних баскетбольних збірних команд світу.

Методи досліджень: аналіз літературних джерел та мережі Інтернет, педагогічне спостереження, аналіз змагальної діяльності, відеоаналіз ігор, методи математичної статистики.

Результати дослідження та їх обговорення. Нами було проаналізовано ігри чоловічих (30) та жіночих (30) національних збірних команд на чемпіонаті світу з баскетболу $3 \times 3$ 2019 р. (Амстердам). Досліджувались

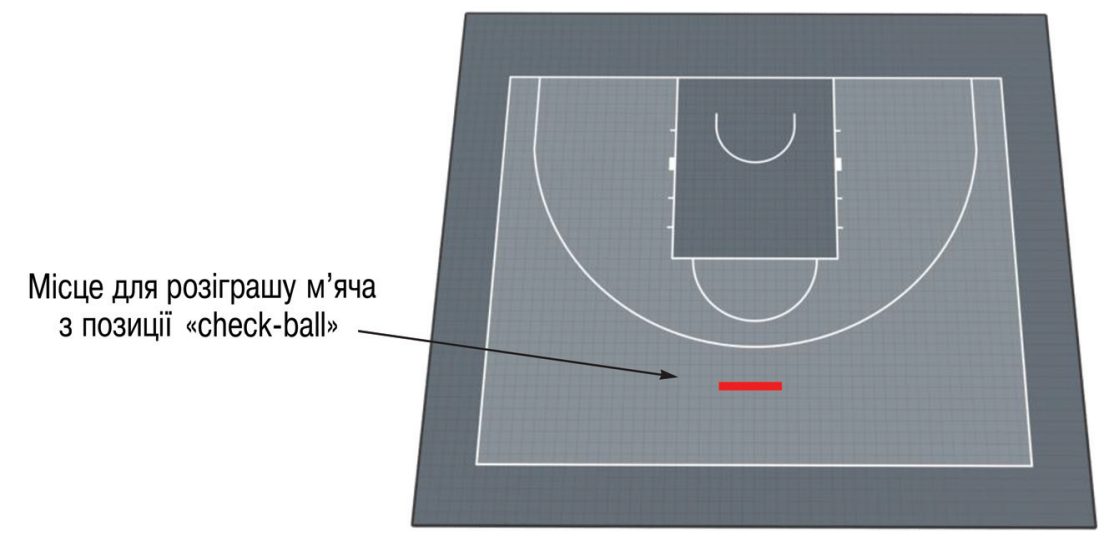

Рисунок 1 - Позиція для розіграшу м'яча зі стандартного положення «check-ball» в баскетболі $3 \times 3$

такі параметри змагальної діяльності: кількість виконаних стандартних положень розіграшу м'яча з позиції «check-ball» протягом гри; кількість реалізованих стандартних положень з позиції «check-ball» за гру; кількість набраних очок в грі з позиції «checkball»; відсоток набраних очок з позиції «check-ball» до загальної суми набраних очок в матчі; кількісно-якісні показники виконання стандартних положень з позиції «check-ball» в різних частинах гри.

Висока інтенсивність та динамічність змагальної діяльності в баскетболі $3 \times 3$, менша тривалість часу на атаку кошика суперника та щільна боротьба на корті обумовлюють нетривалість ігрових відрізків та значну кількість пауз в грі. Кожна вимушена зупинка в грі (аут м'яча, фол, тайм-аут тощо) поновлюється розіграшем м'яча зі стандартного положення «check-ball» (рис. 1).

При цьому, на самому корті сьогодні відсутня чітка лінія або позначка, яка вказувала б на те, де саме необхідно вводити м'яч у гру. Найчастіше баскетболіст, який починає розіграш стандартного положення «check-ball», знаходиться в центрі майданчика за дугою (позиція «tор») приблизно на метр від цієї лінії. М'яч вводиться в гру після того, як гравець команди суперника передає його гравцю, що знаходиться в позиції «тор». Після того, як гравець команди суперника передав м'яч гравцю команди, що атакує, вмикається таймер володіння і у команди є 12 с для того, щоб здійснити атаку кошика
Зупинки в грі можуть мати важливе тактичне значення для команди. Адже під час 10-15-секундної паузи є час на відновлення та раціональну організацію дій спортсменів під час розіграшу м'яча з позиції «check-ball». Досить часто можна спостерігати ситуацію, коли команда свідомо дає вийти м'ячу за межі корту для того, щоб отримати право на подальший розіграш 3 вигідного стандартного положення позиції «check-ball».

Проведені нами дослідження матчів чоловічих та жіночих національних збірних команд на чемпіонаті світу 3 баскетболу $3 \times 32019$ р. в Амстердамі показали, що, в середньому, команда виконує до $11 \pm$ 0,68 стандартних положень за матч (рис. 2). При цьому достовірних відмінностей між чоловічими та жіночими командами не спостерігалось. Чоловічі команди дещо краще реалізовували свої спроби розіграшу м'яча з позиції «check-ball» 4,33 \pm 3,60 проти 3,93 $\pm 2,17$ у жінок, хоча ці відмінності не мали статистично достовірного характеру ( $p>0,05)$.

Представлені дані мають середньостатистичний характер для всіх збірних команд на турнірі. Показники реалізації розіграшу м'яча провідними збірними командами світу з позиції «check-ball» значно вищі. В деяких чоловічих та жіночих командах ефективність реалізації досягає 50 \% і вище (Сербія, Франція, Латвія та ін.).

Враховуючи той факт, що команда має в грі більше одинадцяти спроб для реалізації стандартного положення з позиції «check-ball», можна очікувати, за якісного їх виконання, на май- 


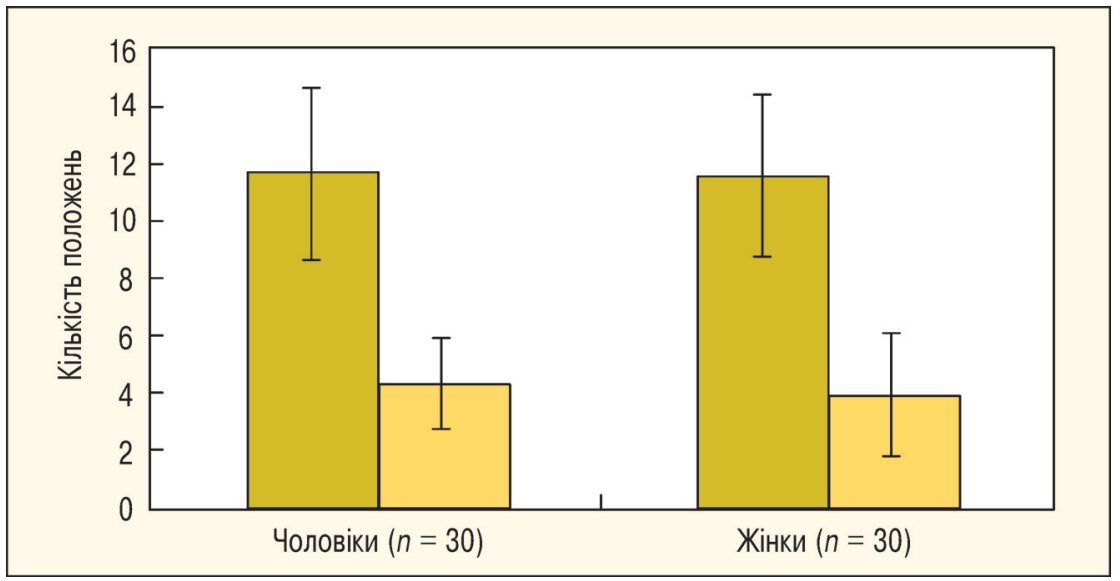

Рисунок 2 - Загальна кількість та есрективність атак 3 позиції «check-ball» чоловічими та жіночими національними збірними командами на чемпіонаті світу з баскетболу $3 \times 3$ у 2019 p.:

$\square$ - загальна кількість «чеків» за гру; $\square$ - кількість реалізованихщчеків» за гру

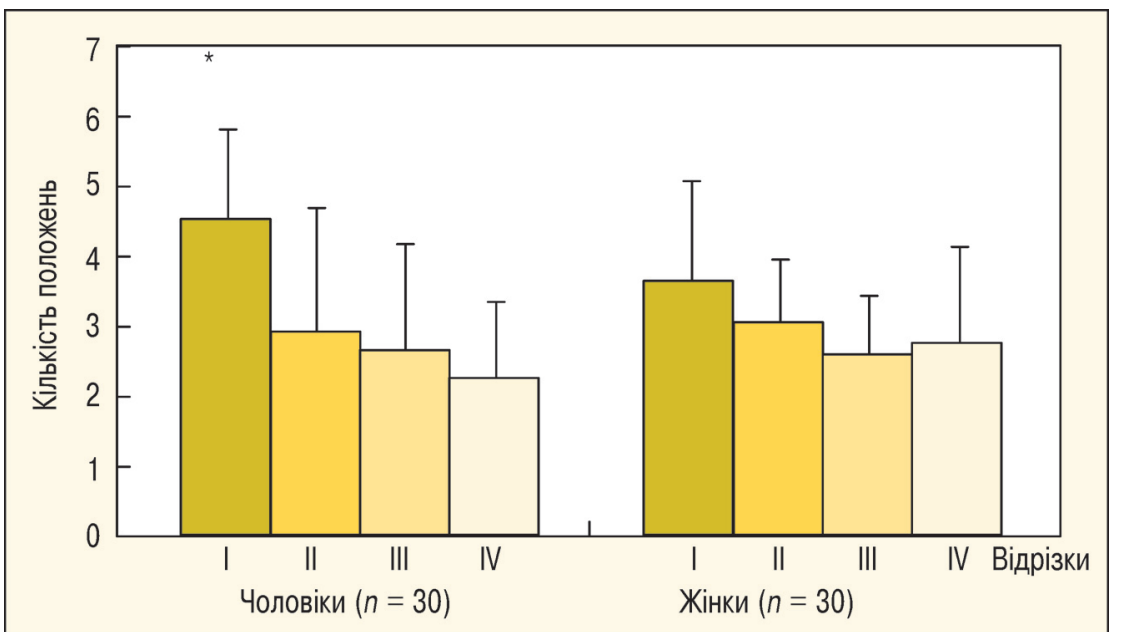

Рисунок 3 - Загальна кількість атак з позиції «check-ball» національними збірними командами в різних відрізках гри

же половину всіх набраних очок у матчі.

Резерв для вдосконалення змагальної діяльності команд в баскетболі 3 × 3 за рахунок якісного розіграшу стандартних положень при цьому $€$ цілком очевидним.

Цікавим, на наш погляд, було дослідження особливостей виконання та реалізації стандартних положень у різних проміжках гри. На відміну від класичного баскетболу матч $3 \times 3$ не розподілений на чверті. Значні паузи в грі виникають переважно лише під час тайм-аутів (30 c), які за своєю тривалістю удвічі менші порівняно з класичним баскетболом.

Лімітована кількість гравців команди (три на майданчику і один на заміні) та висока інтенсивність ру- ний розподіл гри на чотири рівні відрізки (по 25 \% кожний): перший - 100-75\% часу $(10,00-7,30$ хв), другий - 75-50\% (7,30-5,00 хв), третій - 50-25\% (5,002,30 хв), четвертий $-25-0 \%$ (2,30 Хв - до завершення матчу).

Саме за таким принципом ми вирішили здійснити аналіз ефективності реалізації стандартних положень «check-ball» чоловічими та жіночими національними збірними командами в матчах групового етапу та серії плейофр чемпіонату світу 2019 р. (рис. 3).

Найбільша кількість атак через розіграш стандартного положення «check-ball» («чек») спостерігається в перші 2,5 хв матчу. Подібна тенденція відмічається як у чоловічих, так і в жіночих командах. Для чоловічих команд ці показники мають достовірний характер порівняно із кількістю виконаних «чеків» в інші відрізки гри $(p<0,05)$. Так, у середньому, 40ловіча команда високого класу виконує за перші 2,5 хв 4,55 $\pm 1,75$ «чеків», в інших трьох відрізках - 2,94 $\pm 1,24$, 2,68 \pm 1,49 та 2,29 \pm 1,07 відповідно.

Жіночі команди мали в першому відрізку дещо менший рівень показників виконання «чеків» порівняно із чоловіками $-3,68 \pm 1,69$, проте цей показник, як і у випадку із чоловічими командами, був вищим, ніж дані наступних трьох відрізків.

Такий нерівномірний розподіл кількості стандартних положень розіграшу м'яча 3 позиції "check-ball» в різних відрізках матчу (особливо в перші 2-3 хв порівняно з іншими) можна спробувати пояснити вищою динамічністю та інтенсивністю гри на перших хвилинах протистояння. Спортсмени виконують значну кількість швидких атак, більш якісно працюють у захисті, що веде до збільшення зупинок у грі (фоли, аути тощо) та обумовлює подальшу необхідність введення м'яча з позиції «check-ball».

Подібна ігрова агресивність перших хвилин матчу, особливо у захисті, на наш погляд, пояснює іншу цікаву статистику, яку ми отримали, аналізуючи якість відсоткової реалізації атак 3 позиції «check-ball» в різних відрізках гри. При зменшені загальної кількості атак 3 позиції «check-ball» від першого до четвертого відрізку збільшується відсоток їх реалізації (рис. 4). Подібна тенденція спостерігається як 
у чоловічих, так і в жіночих збірних командах. Цілком можливо, що той стан втоми, який спостерігається на останніх хвилинах матчу, суттєвим чином впливає на рівень концентрації та швидкості рухів гравців у захисті, які починають робити тактичні помилки під час протидії організованим комбінаційним взаємодіям суперника.

Чоловічі національні збірні команди протягом останніх 2,5 хв ігрового часу демонструють ефективність реалізації розіграшу м'яча з позиції «check-ball» на рівні 55,36 $\pm 32,57 \%$. Ці відмінності мають статистично достовірний характер $(p<0,05)$ порівняно із двома першими відрізками матчу.

У змагальній діяльності жіночих національних збірних команд було відмічено дещо менш виразну динаміку збільшення відсотка реалізації «чеків» від першого до останнього відрізку 10 хв гри.

Особливої уваги, на наш погляд, заслуговує аналіз ефективності реалізації стандартних положень «checkball» лідерами світового баскетболу $3 \times 3$ та їх порівняння із даними інших команд.

Отримані статистичні дані дозволили створити усереднену модель реалізації атак $з$ позиції «check-ball» та здійснити порівняльний аналіз національних збірних команд різних країн у цьому компоненті змагальної діяльності на турнірі (рис. 5).

Серед жіночих команд найбільш есективно реалізовували свої атаки з позиції «check-ball» баскетболістки національної збірної Китаю, яка й здобула золоті нагороди чемпіонату світу 2019 р. Вона порівняно 3 іншими збірними командами мала найбільшу кількість спроб організації атак 3 позиції «check-ball» - 14,23 \pm 3,29 за гру. Вражаючим є відсоток реалізації атак зі стандартного положення - 56,11 $\pm 8,98 \%$ (див. рис. 5). Майже половину своїх очок у матчі $(44,03 \pm 7,89 \%)$ жіноча збірна Китаю здобувала завдяки раціонально організованим тактичним взаємодіям своїх спортсменок під час розіграшу м'яча зі стандартних положень.

Високий рівень реалізації атак 3 позиції «check-ball» спостерігався і у багаторічного лідера жіночого баскетболу $3 \times 3$ національної збірної команди Франції. Спортсменки реалізовували майже кожен другий «чек» на чем- піонаті світу 2019 р. $(45,37 \pm 9,07 \%)$. Проте внесок набраних очок з позиції «чек» у загальну їх кількість у матчі значно менший порівняно, наприклад, із китайською збірною $(27,71 \%)$. Французька збірна команда в середньому набирала на турнірі 20 очок в матчі, переважну більшість яких було здобуто в активній фразі безперервних ігрових дій.

Недостатньо есрективною можна вважати реалізацію стандартних положень «check-ball» національною жіночою збірною командною України на цьому турнірі. Лише кожен четвертий розіграш м'яча 3 позиції «check-ball» виявився результативним $(24,15 \pm 10,6 \%)$. Загальний внесок очок, набраних з позиції «check-ball», по відношенню до сумарної їх кількості становив лише 23,78 \%. Практично за всіма досліджуваними показниками жіноча збірна команда України мала нижчі показники від середніх модельних значень.

Дискусія. Детальний аналіз особливостей реалізації стандартних положень командою суперника напередодні протистояння, виявлення сильних та слабких сторін підготовленості опонента під час розіграшу м'яча з позиції «check-ball» може стати важливим аргументом у майбутній боротьбі.

Сьогодні під час скаутингу команди суперника переважно аналізуються тактичні взаємодії та комбінації, які він використовує у своїй змагальній діяльності, в тому числі під час розіграшу стандартних положень 3 позиції «check-ball». При цьому дуже мало уваги приділяється питанням якості реалізації цих комбінацій, наскільки значною $є$ ставка суперника на ефективність виконання стандартних положень, скільки очок набирає командасуперник у матчі завдяки реалізації атак з позиції «чек».

Під час розіграшу м'яча з позиції «check-ball» команді, що атакує, необхідно отримати одну із ситуативних переваг. При цьому вдалий початок комбінаційних взаємодій гравців можна вважати першою фазою цього розіграшу (вдалий розмін, або виведення гравця на вільний кидок). Друга фраза - це ефективність завершення атаки (кидок, обіграш один в один із подальшим кидком тощо), що значною мірою залежить від рівня інди відуальної техніко-тактичної майстерності гравця, який завершує розіграну комбінацію.

Найбільш сприятливою ситуативною (або оперативною) перевагою, яка може виникнути під час розіграшу стандартного положення 3 позиції «check-ball», є прямий вихід гравця для атаки з-під кошика, або створення умов для вільного кидка з різних дистанцій.

Подібну перевагу досягають переважно за рахунок вдало виконаного заслону гравцеві з м'ячем (on ball screen) або гравцеві без м'яча (off ball screen). Вільний вихід гравця нападу для атаки кошика суперника після розіграшу стандартного положення свідчить про незадовільні дії захисників через непорозуміння під час про-

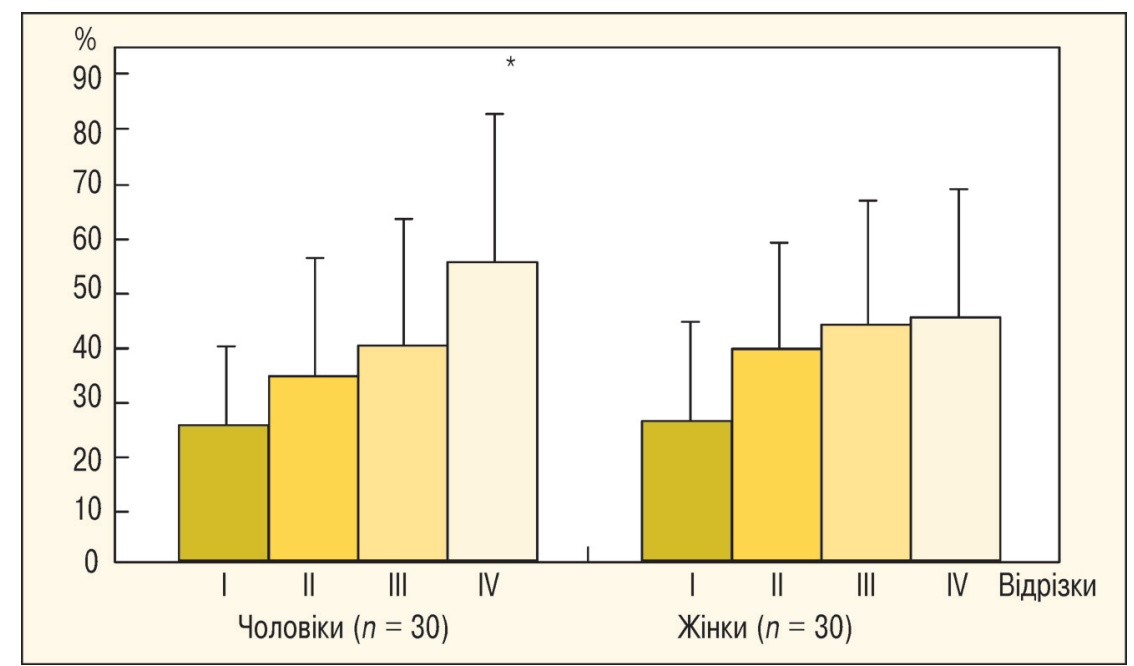

Рисунок 4 - Відсоток реалізації атак з позиції «check-ball» національними збірними командами в різних відрізках гри 


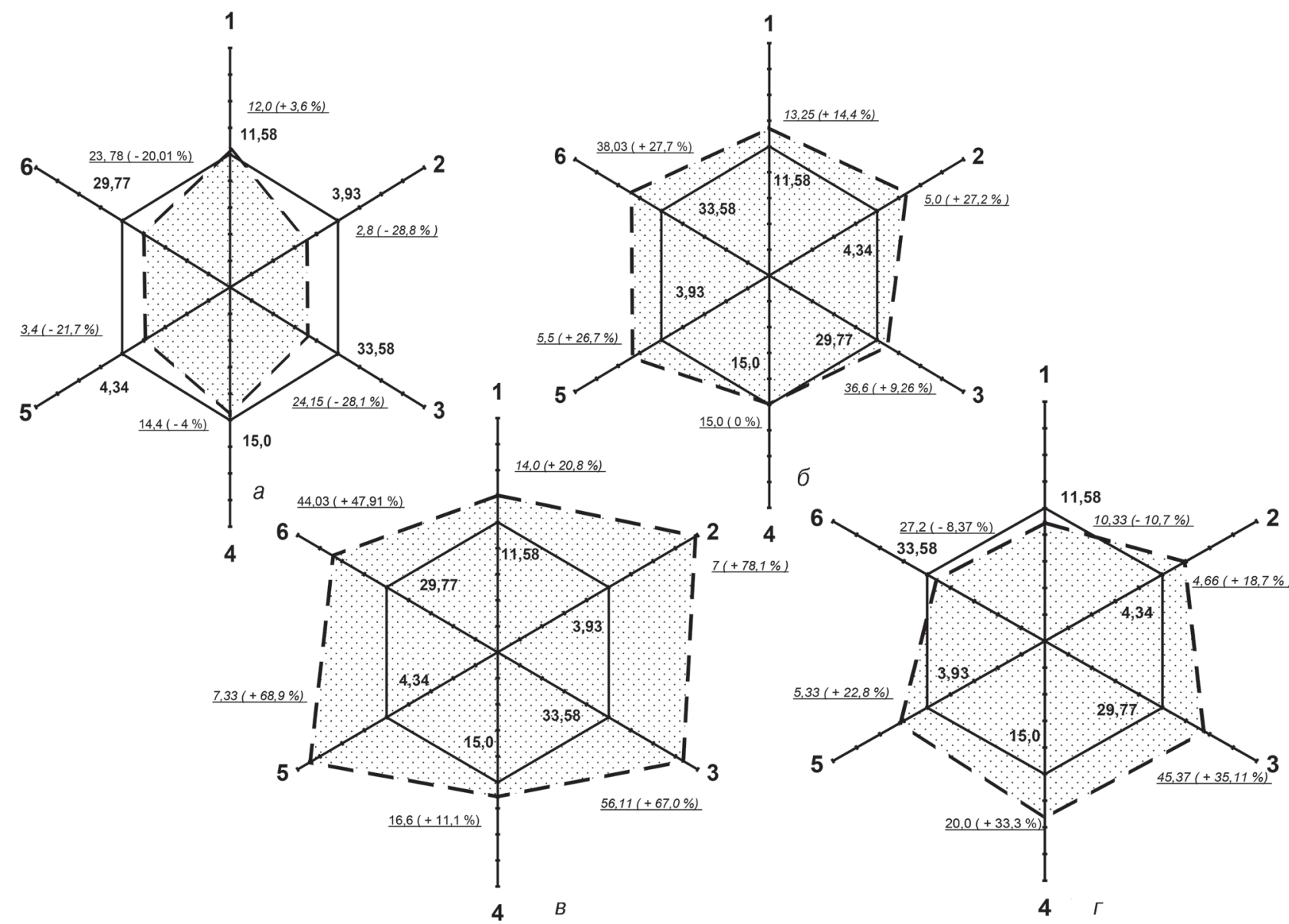

Рисунок 5 - Реалізація атакувальних дій жіночими баскетбольними збірними командами на чемпіонаті світу 2019 р. порівняно 3 модельними (середніми) показниками: країни:

a - Україна; б - Австралія; в - Китай; г- Франція; 1 - загальна кількість «чеків» за матч (у середньому); 2 - загальна кількість реалізованих «чеків» за матч; 3 - відсоток реалізації «чеків» за матч; 4 - кількість набраних очок на турнірі в середньому за матч; 5 - кількість набраних очок з позиції «чек»; 6 - відсоток набраних очок з позиції «чек» (у середньому за матч)

ходження заслонів та погану комунікацію. Такий розвиток ситуації для команди нападу $є$ найбільш бажаним. Сьогодні існує велика кількість різноманітних варіантів взаємодій гравців під час використання «PNR» та заслонів без м'яча (рис. 6).

Дуже часто на змаганнях найвищого рівня команди під час розіграшу мяча з позиції «check-ball» використовують так званий «обманний заслон» (fake screen). Різка зміна напрямку руху гравця у бік кошика замість постановки заслону часто є зовсім неочікуваним продовженням комбінації для захисників. На відміну від класичного баскетболу в баскетболі $3 \times 3$ після такого маневру з боку нападаючого у бік кошика зустріти цього гравця вже нікому.

Проте подібне вільне завершення атаки в баскетболі $3 \times 3$ сьогодні зу- стрічається не так часто, особливо на змаганнях найвищого рівня.

Іншою бажаною ситуативною перевагою, яка може виникнути під час розіграшу «check-ball», $€$ нерівноцінний розмін гравців за позиціями («mismatch» - 3 англ. невідповідність).

На відміну від класичного баскетболу, до складу команди з баскетболу $3 \times 3$ намагаються залучати спортсменів, які мають проміжні тотальні розміри тіла. Подібний рівний за антропометрією та фрізичними даними склад дозволяє одразу ж зняти проблему нерівноцінного розміну під час проходження заслонів та уникнути багатьох непорозумінь під час взаємодії у захисті.

У класичному баскетболі - це зазвичай гравці, які виконують на майданчику функції захисників та «легких фрорвардів». Переваги, які мають «великі» повільні баскетболісти в баскетболі $5 \times 5$, практично втрачають- ся в баскетболі $3 \times 3$. Адже ситуація розвивається настільки динамічно та швидко, що габаритні центрові просто не встигають за розвитком подій та можуть стати слабкою ланкою у змагальній діяльності команди.

Схожі проблеми очікують і на «маленьких» гравців (класичні «перші номери»). Отримавши перевагу в швидкості під час обіграшу суперника та кидках 3 дальньої дистанції, команда стає більш вразливою під кошиком. «Маленький» гравець $є$ бажаною мішенню для команди суперника під час виконання заслонів. Саме 3 такими гравцями найчастіше й намагаються здійснити нерівноцінний («mismatch») розмін для отримання переваги під кошиком. Перебування «маленького» гравця на майданчику одразу ж відкриває для суперника різні варіанти взаємодій для досягнення 

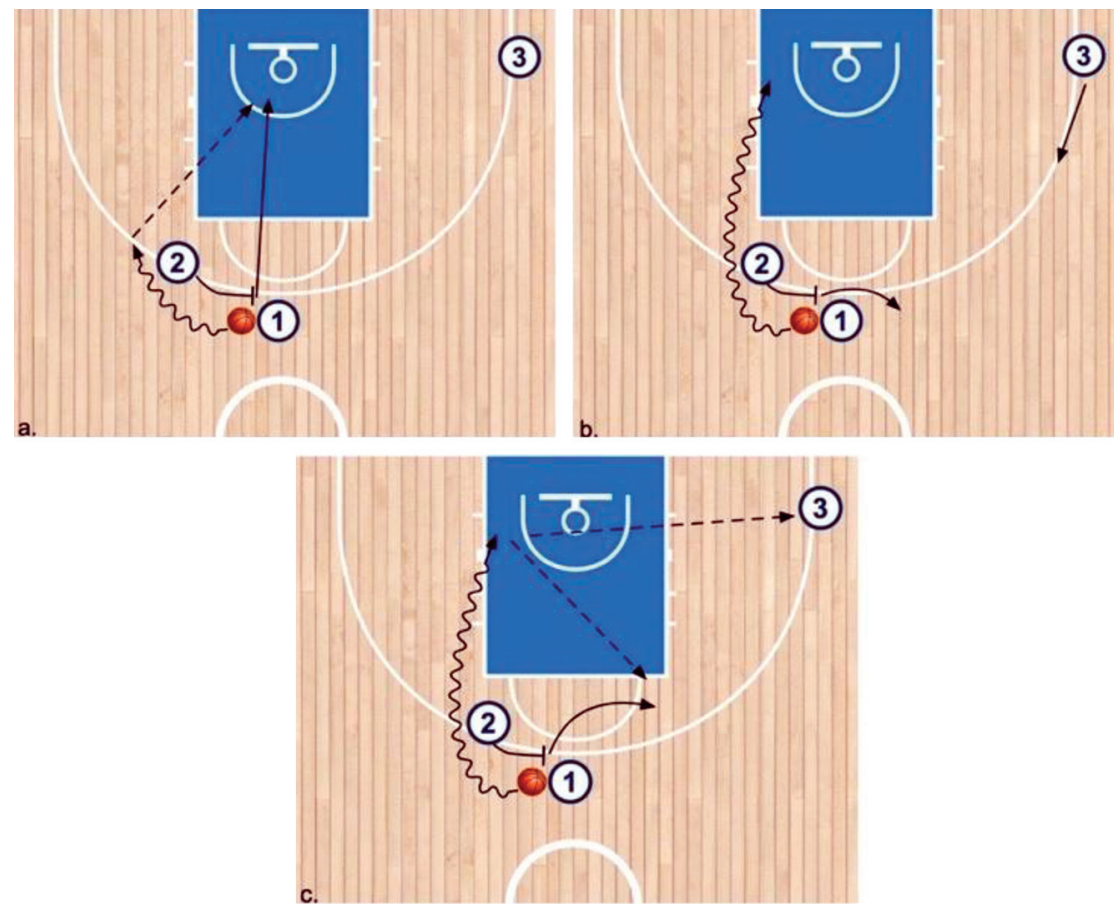

Рисунок 6 - Розіграш стандартного положення «check-ball» 3 використанням «PNR» жіночою національною збірною командою Австралії

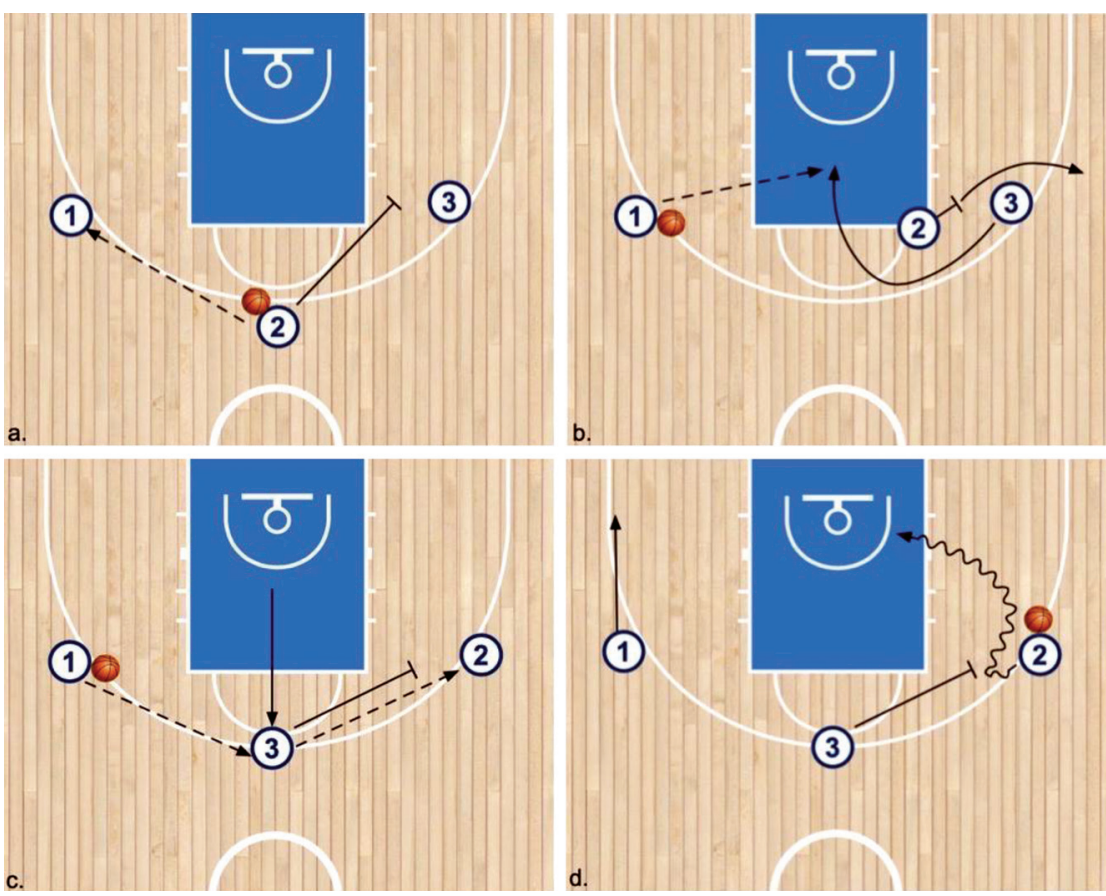

Рисунок 7 - Варіант організації взаємодій гравців жіночої збірної команди Франції під час розіграшу стандартного положення «check-ball»

ситуативної переваги, у тому числі й 3 позиції «check-ball» (рис. 7).

Попри це в деяких провідних жіночих баскетбольних збірних командах (Італії, Франції, Японії) саме «маленькі» гравці виконують одну із основних ролей на майданчику, а існуючі міну- чно більша на відміну від класичного баскетболу, адже варіант страховки та допомоги в даному випадку стратегічно недоцільний та небезпечний. Здійснивши допомогу своєму партнеру, гравець залишає власного нападаючого на вільній позиції, зазвичай за дугою. Такий розвиток ситуації є ще більш загрозливим для команди, яка захищається, ніж нерівноцінний розмін за позиціями.

У випадках, коли склади команд суперників приблизно рівні за своїми антропометричними даними і варіант нерівноцінного розміну за позиціями є неможливим, доцільним вважаються дії команди, спрямовані на створення сприятливих умов для найбільш майстерного гравця команди для подальшого обіграшу суперника один в один (рис. 9).

Дуже часто такий гравець через серію заслонів та розмінів виводиться на найбільш слабкого захисника команди суперника для завершення атаки в отриманих сприятливих умовах. Інші два гравці нападу при цьому повинні забезпечити необхідний тактичний простір («spacing») для того, щоб виключити варіант допомоги з боку інших захисників.

Під час планування та організації комбінаційних тактичних взаємодій гравців з позиції «check-ball» потрібно враховувати ряд важливих умов та обставин:

1. Склад своєї команди. Наявність у команді високих та рухливих гравців дозволяє значно розширити арсенал ігрових взаємодій на позиції «Low post», використовувати перевагу нерівноцінного розміну за позиціями, за наявності у складі команди суперника «маленьких» гравців тощо. Якщо команда має у своєму складі швидких невисоких баскетболістів з ефективним дальнім кидком, доцільним $€$ зміщення акценту в змагальній діяльності на проходи під кошик та пошук вільного гравця («снайпера») на позиції дальнього кидка.

Команда повинна використати власні переваги та мінімізувати сильні сторони змагальної діяльності суперника. При цьому тренерських штаб може використовувати різні підходи в процесі комплектування команди. Свідомо обирати гравців з бажаною антропометрією та навичками під власну 


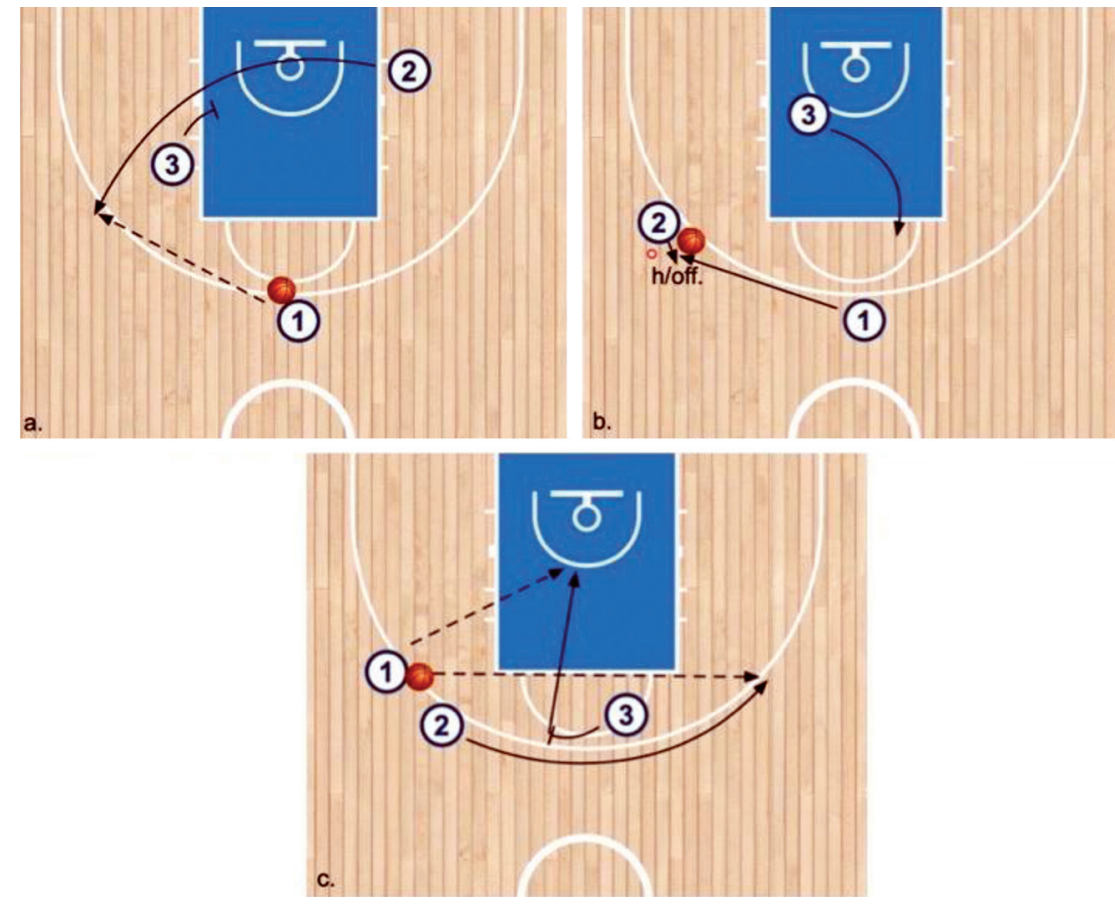

Рисунок 8- Варіант організації взаємодій гравців жіночої збірної команди Японії під час розіграшу стандартного положення «check-ball»
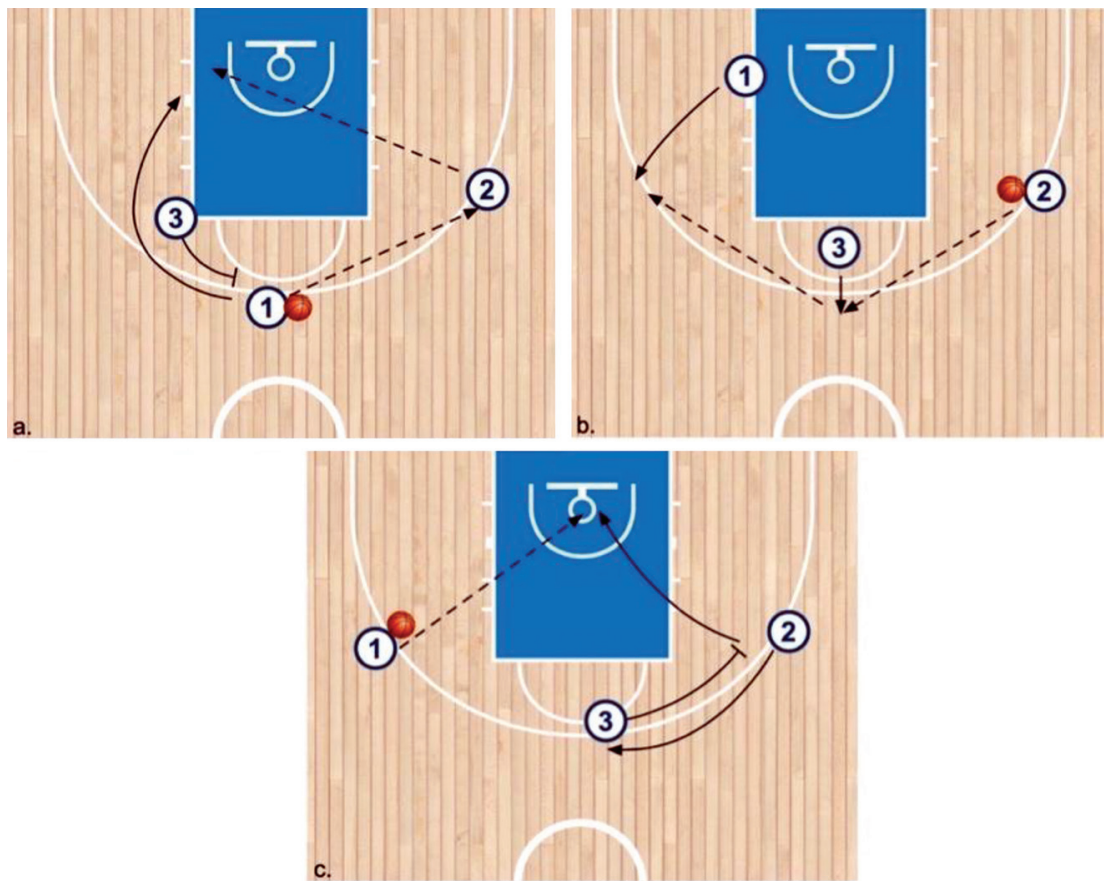

Рисунок 9- Варіант організації взаємодій гравців жіночої збірної команди Угорщини під час розіграшу стандартного положення «check-ball»

концепцію гри (консервативний підхід) і адаптувати їх до прийнятих раніше тактичних схем гри, або обирати варіанти тактичних взаємодій з урахуванням можливостей гравців, які на даному етапі підготовки опинилися у розпорядженні тренерського штабу команди (лабільний підхід).
2. Склад команди суперника. Невисокі гравці команди-суперника зобов'язують використовувати власних габаритних гравців під кошиком та здійснювати атаку з ближніх дистанцій. I навпаки, високий зріст гравців команди-суперника (наприклад, жіноча збірна Канади) практично нівелює переваги, які можуть бути отримані в грі під кошиком. У грі проти таких команд основну увагу потрібно приділяти тактичним взаємодіям гравців, які допоможуть здійснити вільний дальній кидок або виконати обіграш один в один з подальшим проходом під кошик тощо (рис. 10).

3. Новизна обраних комбінацій. Важливим елементом підготовки команди до змагань $€$ відеоскаутинг структури змагальної діяльності суперника. Вивчаються як індивідуальні техніко-тактичні і фізичні можливості окремих спортсменів, так і найбільш улюблені варіанти взаємодій команди, в тому числі і з позиції «check-ball».

Якщо команда протягом тривалого часу використовує одні й ті самі схеми тактичних взаємодій гравців, це значно полегшує супернику завдання завчасної підготовки для майбутнього протистояння. Команда, яка добре ознайомлена із послідовністю тактичних дій свого суперника, має значну перевагу у матчі, може діяти на випередження та ефективно руйнувати підготовлені напрацювання опонента.

Саме тому важливим завданням підготовки до змагань $€$ включення нових комбінацій і тактичних взаємодій. Використання нових варіантів розіграшу м'яча з позиції «check-ball» може стати неприємним сюрпризом для команди-суперника та принести чималий зиск для досягнення позитивного результату в матчі (рис. 11).

4. Оперативна ситуація під час матчу. Спортсменам необхідно швидко пристосовуватись до змін, які відбуваються по ходу поєдинку. Потрібно оперативно реагувати на заміни гравців, які постійно відбуваються в матчі, використовувати оперативну перевагу над суперником у кожній конкретній ситуації. Поширеними $є$ випадки, коли заготовлений на гру план повністю руйнується вже з перших хвилин матчу і команді потрібно миттево підлаштовуватись під ту ситуацію, яка розгортається в даний момент на майданчику. Спортсмен, який вдало увійшов у гру та демонструє високу есрективність реалізації кидків, повинен постійно бути у полі зору партнерів по команді. Саме під такого гравця 

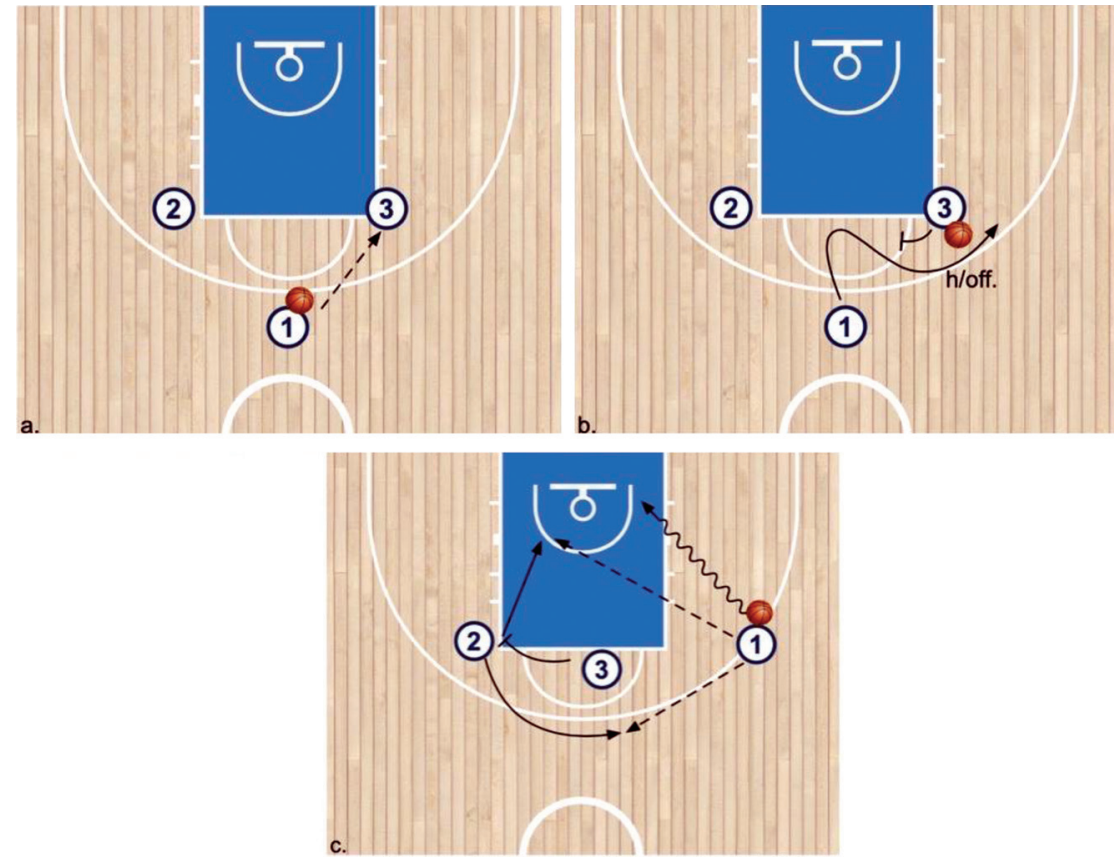

Рисунок 10 - Варіант організації взаємодій гравців жіночої збірної команди Китаю під час розіграшу стандартного положення «check-ball»

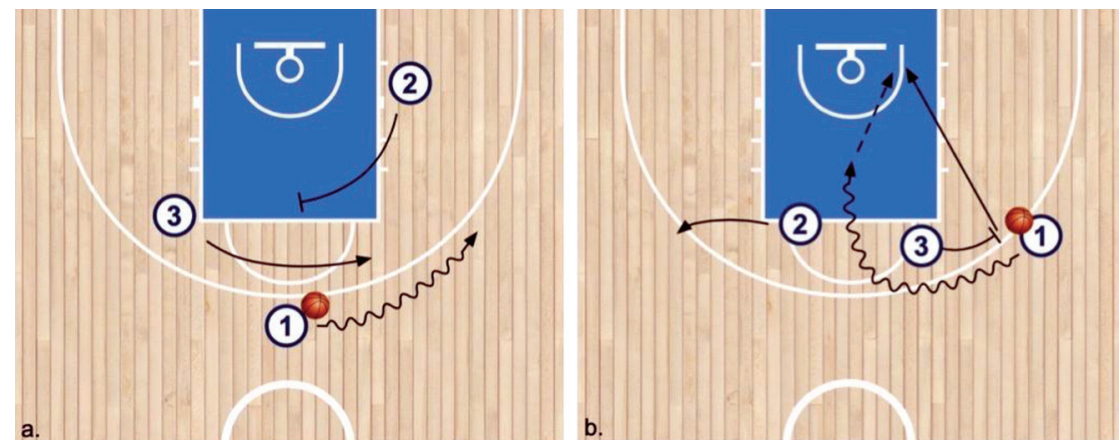

Рисунок 11 - Варіант організації взаємодій гравців жіночої збірної США під час розіграшу стандартного положення «check-ball»

доцільно обирати варіант взаємодії з позиції «check-ball».

Необхідно враховувати загальний рахунок у матчі. В баскетболі $3 \times 3$ ігровий час хоча й лімітовано, але результат може бути досягнуто достроково (якщо одна з команд набере 21 очко). В тих випадках, коли команда суперника наближається до позначки в 21 очко, вочевидь, доцільнішою виглядає підготовка атаки 3 дальньої дистанції, що дозволить швидше наздогнати суперника.

Під час додаткового часу (overtime) більшість команд під час розіграшу стандартного положення з позиції «check-ball» орієнтується саме на підготовку дальнього (двоочкового) кидка. Точне влучання із-за дуги одразу приносить команді перемогу у додатковий час (гра в якому триває до двох набраних очок однією із команд). Саме завдяки атаці з дальньої дистанції жіноча збірна команда України здобула у додатковий час бронзові нагороди чемпіонату Європи 2018 р.

Важливою обставиною, яка повинна впливати на вибір та організацію взаємодій гравців у баскетболі $3 \times 3, \epsilon$ кількість фролів команди суперника. В цьому виді баскетболу не існує персональних зауважень, а є лише командні. При отриманні сьомого командного фолу команда карається пробиттям двох штрафрних кидків, а після отримання десятого - суперник після пробиття двох штрафрних ще й отримає право на подальше володіння м'ячем.
У такому фрорматі гри, особливо в заключній частині відведеного ігрового часу, таке покарання $€$ надзвичайно важким для команди.

у тих випадках, коли командасуперник має шість і більше фолів, украй важливо орієнтуватися на контактний прохід під кошик суперника. При цьому в опонента залишається небагато варіантів захисту. Перший - послабити тиск та грати обережно 3 нападаючим для того, щоб уникнути пробивних фолів, другий - навпаки, грати контактно зі значним ризиком отримання фолу. Обидва варіанти є сприятливими для команди, що атакує.

Викликає подив невикористання переваг цієї ситуації деякими командами навіть на найвищому рівні. Замість того, щоб реалізувати перевагу командних фолів суперника, гравці починають виконувати поспішні та непідготовлені атаки з дальньої та середньої дистанції. Можливо це можна спробувати пояснити тим станом явної втоми, який виникає в організмі спортсменів наприкінці поєдинку. Адже саме на останніх хвилинах матчу й виникають подібні ситуації.

Детальний аналіз специфрічних умов змагальної діяльності в баскетболі $3 \times 3 \in$ одним із перспективних напрямів удосконалення системи підготовки спортсменів для їх подальшого виступу на найпрестижніших міжнародних змаганнях.

Сьогодні фахівцям лише частково вдалося розкрити ті специфрічні умови змагальної діяльності, які є характерними для баскетболу $3 \times 3$. Більшість фрундаментальних досліджень ще попереду. Очевидним $є$ необхідність розробки специсрічної моделі річної періодизації підготовки команд у баскетболі $3 \times 3$ з урахуванням постійного збільшення кількості змагань та особливостями фізичних та фуннкціональних навантажень в цьому новому виді спорту. Практично недослідженими залишаються проблеми спортивного відбору та організації багаторічної підготовки спортсменів у баскетболі 3 × 3 та інші актуальні питання.

\section{Висновки:}

1. Створення власної міжнародної системи спортивних змагань та включення баскетболу $3 \times 3$ до програми 
Ігор Олімпіад обумовило подальший самостійний вектор розвитку цього різновиду баскетболу. Кількість престижних змагань та їх учасників продовжує постійно зростати, хоча в баскетболі $3 \times 3$ сьогодні практично недослідженими залишаються фундаментальні проблеми спортивної підготовки. Одним із перспективних напрямів удосконалення системи підготовки спортсменів в баскетболі $3 \times 3$ $€$ дослідження особливостей змагальної діяльності та визначення ключових фракторів її реалізації та забезпечення.

2. Одним зі шляхів підвищення ефективності змагальної діяльності команд високої кваліфрікації в баскетболі $3 \times 3$ якісна реалізація розіграшу м'яча з позиції «check-ball». Протягом гри команди здійснюють у середньому $11 \pm 0,68$ розіграшів стандартних положень з позиції «check-ball», із яких лише 35-50 \% є результативними. Найбільша кількість розіграшів м'яча припадає на перші 2-3 хв поєдинку. Подібна тенденція спостерігалась як для чоловічих, так і для жіночих національних збірних команд. При цьому найбільш ефективно стандартні положення команди виконували в заключні хвилини гри і найменш есрективно - на її початку. Для чоловічих команд ці відмінності мали статистично достовірний характер $(p<0,05)$.

3. Під час організації командних взаємодій у розіграші м'яча з позиції «check-ball» потрібно враховувати ряд важливих умов та обставин: 1) склад своєї команди. Важливим є використання переваг власних гравців, які знаходяться в конкретний момент ігрового часу на майданчику порівняно із гравцями команди-суперника; 2) склад команди суперника. Пошук шляхів протидії сильним сторонам команди суперника і розуміння власних переваг під час організації стандартних положень; 3) новизна обраних комбінацій. Постійний творчий пошук нових ефективних варіантів тактичних взаємодій гравців, який ускладнює завчасну підготовку команди-суперника до протистояння; 4) оперативна ситуація під час матчу. Прийняття тактичних рішень, виходячи із сценарію розвитку подій, які відбуваються у матчі (кількість фролів, час на атаку кошика, заміни гравців тощо).

Перспективи подальших досліджень пов'язані із розробкою моделей річної періодизації підготовки професійних спортсменів у баскетболі $3 \times 3$.

Конфлікт інтересів. Автори заявляють, що відсутній будь-який конфрлікт інтересів

\section{ЛІТЕРАТУРА}

1. Иссурин ВБ. Подготовка спортсмена XXI века. Научные основы и построение тренировки. Москва: Спорт; 2016. 464 с.

2. Платонов ВН. Система подготовки спортсменов в олимпийском спорте. Общая теория и ее практические приложения: учебник в 2 кн. Киев: Олимпийская лит.; 2015. Кн. 1.680 с.

3. Bompa T, Haff G. Periodization: Theory and Methodology of Training. IL: Kinetics H, editor; 2009. P. 411

\section{ІНФОРМАЦІЯ ПРО АВТОРІВ}

Холопов Володимир Михайлович https:orcid.org/0000-0002-9563-2427, e-mail: kholopov. vladymyr@gmail.com Федерація баскетболу України 04108, Київ, вул. Н. Ужвій 6 ,

Безмилов Микола Миколайович https:orcid.org/0000-0001-7379-9851, kaupervud2020@ukr.net Федерація баскетболу України 04108, Київ, вул. Н. Ужвій 6 ,

Національний університет фізичного виховання і спорту України 03150, Київ, вул. Фізкультури, 1

\section{INFORMATION ABOUT THE AUTHORS}

Kholopov Vladimir https:orcid.org/0000-0002-9563-2427, e-mail: kholopov.vladymyr@gmail.com Ukraine basketball Federation 04108, Kiev, st. N. Ygviy 6 ,

Bezmylov Nikolay https:orcid.org/ 0000-0001-7379-9851, kaupervud2020@ukr.net Ukraine basketball Federation 04108, Kiev, st. N. Ygviy 6,

National University of Ukraine on Physical Education and Sport, 03150, Kyiv, Fizkul'tury str., 1
4. Conte D, Straigis E, Clemente FM, Gómez MA, Tessitore A. Performance profile and gamerelated statistics of FIBA $3 \times 3$ Basketball World Cup 2017. Biology sport; 2019. 36 (2): 149-154.

5. Erculj F, Vidic M, Leskošek B. Shooting efficiency and structure of shooting in $3 \times 3$ basketball cooperated to 5 Ḱ 5 basketball. International journal of Sports Science \& Coaching; 2019. 15 (1).

6. Herrán A, Usabiaga 0 , Castellano J. Comparacion del perfit físico entre $3 \times 3$ y $5 \times 5$ en baloncesto formatio. Physical Profile Comparison Between $3 \times 3$ and 5 Ḱ 5 Basketball Training. Revista Internacional de Medicina y Ciencias de la Actividad Física y el Deporte; 2017. 17 (67): 435-447.

7. Montgomery PG, Maloney BD. $3 \times 3$ Basketball: Performance Characteristics and Changes During Elite Tournament Competition. International Journal of Sports Physiology and Performance, 19 Nov. 2018: 1-8.

8. Montgomery PG, Maloney BD. $3 \times 3$ Basketball Competition: Physical and physiological characteristics of elite players. J Phy Fit Treatment \& Sports; 2018.5 (3)

9. Sampaio J, Abrantes C, Leite N. Power, heart rate and perceived exertion responses to $3 \times 3$ and $4 \times 4$ basketball small-sided games. Revista de Psicologia del Deporte; 2019.

10. FIBA History: The birth of $3 \times 3$ basketball: International Basketball Federation. [Електронний pecypc].

11. FIBA $3 \times 3$ Rules of the Game: International Basketball Federation. [Електронний ресурс].

\section{LITERATURE}

1. Issurin VB. Training of an athlete of the $X X I$ century. Scientific fundamentals of training design. Moscow: Sport; 2016. 464 p.

2. Platonov VN. System of athletes' preparation in the Olympic sport. General theory and its practical applications: textbook in $2 \mathrm{~b}$. Kiev: Olimpiyskaya literature; 2015. Book 1. 680 p.

3. Bompa T, Haff G. Periodization: Theory and Methodology of Training. IL: Kinetics H, editor; 2009. P. 411

4. Conte D, Straigis E, Clemente FM, Gómez MA, Tessitore A. Performance profile and gamerelated statistics of FIBA $3 \times 3$ Basketball World Cup 2017. Biology sport; 2019. 36 (2): 149-154.

5. Erculj F, Vidic M, Leskošek B. Shooting efficiency and structure of shooting in $3 \times 3$ basketball cooperated to 5 ḱ 5 basketball. International journal of Sports Science \& Coaching; 2019. 15 (1).

6. Herrán A, Usabiaga 0 , Castellano J. Comparacion del perfit físico entre $3 \times 3$ y $5 \times 5$ en baloncesto formatio. Physical Profile Comparison Between $3 \times 3$ and $5 \times 5$ Basketball Training. Revista Internacional de Medicina y Ciencias de la Actividad Física y el Deporte; 2017. 17 (67): 435-447.

7. Montgomery PG, Maloney BD. $3 \times 3$ Basketball: Performance Characteristics and Changes During Elite Tournament Competition. International Journal of Sports Physiology and Performance, 19 Nov. 2018: 1-8

8. Montgomery PG, Maloney BD. $3 \times 3$ Basketball Competition: Physical and physiological characteristics of elite players. J Phy Fit Treatment \& Sports; 2018.5 (3)

9. Sampaio J, Abrantes C, Leite N. Power, heart rate and perceived exertion responses to $3 \times 3$ and $4 \times 4$ basketball small-sided games. Revista de Psicologia del Deporte; 2019.

10. FIBA History: The birth of $3 \times 3$ basketball: International Basketball Federation. [Електронний pecypc].

11. FIBA $3 \times 3$ Rules of the Game: International Basketball Federation. [Електронний ресурс].

Надійшла 25.06.2020 